\title{
PEMBELAJARAN STATISTIKA DENGAN MODEL ARIAS PADA SISWA KELAS XI
}

\author{
Herfa Maulina Dewi Soewardini ${ }^{1}$, Meilantifa $^{2}$, Helmy Maulana Priambodo ${ }^{3}$ \\ Universitas Wijaya Kusuma Surabaya, Jalan Dukuh Kupang XXV/54, Surabaya \\ ${ }^{1}$ herfasoewardini_fbs@uwks.ac.id
}

\begin{abstract}
Abstrak
Model pembelajaran ARIAS (Assurance, Relevance, Interest, Assesment, Satisfaction) berperan dalam meningkatkan motivasi dan hasil belajar siswa pada materi Statistika. Tujuan dari penelitian ini adalah untuk mengetahui: (1) Ketuntasan hasil belajar siswa (2) Aktivitas guru mengelola pembelajaran (3) Aktivitas siswa selama pembelajaran. Jenis penelitian ini adalah penelitian deskriptif dengan pendekatan kualitatif dengan rancangan "One Shot Case Study". Subjek penelitiannya adalah seluruh siswa kelas XI-IPS-3 SMA Hang Tuah 1 Surabaya. Metode pengumpulan data yang digunakan adalah metode observasi untuk memperoleh data pengelolaan pembelajaran dan aktivitas siswa serta metode tes untuk mengetahui hasil belajar siswa. Hasil penelitian ini adalah ketuntasan hasil belajar siswa melebihi nilai KKM yaitu $\geq 73$, aktivitas guru dalam mengelola kelas dapat dikategorikan sangat baik, aktivitas siswa yang aktif lebih besar daripada aktivitas siswa yang pasif.
\end{abstract}

Kata Kunci: ARIAS, aktivitas, statistika.

\begin{abstract}
ARIAS learning models (Assurance, Relevance, Interest, Assessment, Satisfaction) play a role in increasing student motivation and learning outcomes in Statistics material. The purpose of this study was to find out: (1) Completeness of student learning outcomes (2) Teacher's activity in managing learning (3) Student activities during learning. This type of research is descriptive research with a qualitative approach with the design of "One Shot Case Study". The research subjects were all students of class XI-IPS-3 Hang Tuah 1 High School in Surabaya. Data collection methods used are observation methods to obtain data on student learning and activity management as well as test methods to determine student learning outcomes. The results of this study are the completeness of student learning outcomes exceeding the KKM value of $\geq 73$, the teacher's activity in managing the class can be categorized very well, active student activity is greater than passive student activity
\end{abstract}

Keywords: ARIAS, activities, statistics.

\section{Pendahuluan}

Pada mata pelajaran matematika khususnya materi Statistika di SMA Hang Tuah, siswa masih nampak kurang semangat dalam belajar dan kurang memahami konsep kuartil, desil, dan simpangan baku. Mereka cenderung diam, namun ada juga yang tidak memperhatikan saat guru menjelaskan materi. Dari observasi yang telah dilakukan, maka dapat diterapkan pembelajaran yang aktif dan bermakna untuk dapat meningkatkan aktivitas dan hasil belajar siswa yaitu dengan model pembelajaran ARIAS. Melalui model pembelajaran ini diharapkan siswa lebih termotivasi, mudah memahami konsep, dan hasil belajarnya meningkat. 
Model pembelajaran ARIAS ini mengklasifikasikan keaktifan dan motivasi belajar menjadi lima komponen yaitu assurance (percaya diri), relevance (berhubungan dengan kehidupan nyata siswa), interest (minat dan perhatian siswa), assesment (evaluasi), dan satisfaction (penguatan). Motivasi dan keaktifan belajar siswa diamati dari perhatian siswa dalam mengikuti pelajaran serta siswa melakukan interaksi dengan guru dan teman-temanya sebagai wujud memahami relevansi isi pembelajaran dengan kebutuhannya.

Model pembelajaran ARIAS merupakan modifikasi dari model ARCS (Attention, Relevance, Confidence, Satisfaction) yang dikembangkan oleh Keller dan Koop (1987:2-9) sebagai upaya merancang pembelajaran yang dapat memengaruhi motivasi berprestasi dan hasil belajar. Model pembelajaran ARIAS terdiri dari lima komponen (Assurance, Relevance, Interest, Assessment, dan Satisfaction) yang disusun berdasarkan teori belajar.

1. Assurance (percaya diri)

Dalam masalah ini, percaya diri yang dimaksud adalah rasa percaya diri pada siswa. Hal ini berkaitan dengan sikap percaya atau yakin akan berhasil atau yang berhubungan dengan harapan untuk berhasil (Keller, 1987:2-9). Beberapa cara yang dapat digunakan untuk mempengaruhi sikap percaya diri adalah. a) Membantu siswa menyadari kekuatan dan kelemahan diri serta menanamkan pada siswa gambaran diri positif terhadap diri sendiri. b) Menggunakan suatu patokan, standar yang memungkinkan siswa dapat mencapai keberhasilan. c) Memberi tugas yang sukar tetapi cukup realistis untuk diselesaikan/sesuai dengan kemampuan siswa. d) Memberi kesempatan kepada siswa secara bertahap, mandiri dalam belajar dan melatih suatu keterampilan.

2. Relevance (relevansi)

Relevance atau relevansi ini berarti dalam pelaksanaan model pembelajaran ARIAS, harus berkaitan dengan pengalaman siswa atau sesuai dengan kehidupan nyata siswa. Beberapa cara yang dapat digunakan untuk meningkatkan relevansi dalam pembelajaran adalah sebagai berikut. a) Mengemukakan tujuan sesuatu yang akan dicapai. Hal ini akan mempengaruhi hasil belajar. b) Mengemukakan manfaat pelajaran bagi kehidupan siswa baik untuk masa sekarang atau untuk berbagai aktivitas di masa mendatang. c) Menggunakan bahasa yang jelas atau contoh-contoh yang ada hubungannya dengan pengalaman nyata atau nilai-nilai yang dimiliki siswa. d) Menggunakan berbagai alternatif strategi dan media pembelajaran yang cocok untuk pencapaian tujuan.

\section{Interest (minat/perhatian)}

Komponen ketiga model pembelajaran ARIAS adalah interest, yaitu aspek yang berhubungan dengan minat/perhatian siswa. Herndon (1987:11-14) menunjukkan bahwa adanya minat/perhatian siswa terhadap tugas yang diberikan dapat mendorong siswa melanjutkan tugasnya. Beberapa cara yang dapat digunakan untuk membangkitkan dan menjaga minat/perhatian siswa antara lain: a) Menggunakan cerita, analogi, sesuatu yang baru, menampilkan sesuatu yang lain/aneh yang berbeda dari biasa dalam pembelajaran. b) Memberi kesempatan pada siswa untuk aktualisasi diri. c) Mengadakan variasi dalam kegiatan pembelajaran. d) Mengadakan komunikasi nonverbal dalam kegiatan pembelajaran seperti demonstrasi dan simulasi.

4. Assesment (penilaian)

Assessment adalah suatu bentuk evaluasi selama proses berlangsungnya kegiatan pembelajaran dari awal hingga akhir. Beberapa cara yang dapat digunakan untuk melaksanakan evaluasi antara lain: a) Mengadakan evaluasi dan memberi umpan balik terhadap kinerja siswa. b) Memberikan evaluasi yang objektif dan adil serta segera menginformasikan hasil evaluasi kepada siswa. c) Memberikan kesempatan kepada siswa mengadakan evaluasi terhadap diri sendiri.d) Memberi kesempatan kepada siswa mengadakan evaluasi terhadap teman.

5. Satisfaction (penguatan) 
Satisfaction yaitu yang berhubungan dengan rasa bangga atau puas atas hasil yang dicapai. Beberapa cara yang dapat dilakukan antara lain: a) Memberi penguatan, penghargaan yang pantas baik secara verbal maupun non verbal kepada siswa yang telah menampilkan keberhasilannya. b) Memberi kesempatan pada siswa untuk menerapkan pengetahuan/ keterampilan yang baru diperoleh dalam situasi nyata atau simulasi. c) Memperlihatkan perhatian yang besar kepada siswa, sehingga mereka merasa dikenal dan dihargai oleh guru. d) Memberi kesempatan kepada siswa untuk membantu teman mereka yang mengalami kesulitan.

Tujuan dari penelitian ini yaitu 1) Mendeskripsikan ketuntasan hasil belajar siswa kelas XI SMA Hang Tuah 1;2) Mendiskripsikan aktivitas guru menggunakan model pembelajaran ARIAS (Assurance, Relevance, Interest, Assesment, Satisfaction); 3) Mendeskripsikan aktivitas siswa menggunakan model pembelajaran ARIAS (Assurance, Relevance, Interest, Assesment, Satisfaction) pada pokok bahasan statistika.

\section{Metode Penelitian}

Jenis penelitian ini adalah penelitian deskriptif dengan pendekatan kualitatif. Penelitian ini dilakukan dengan menerapkan model pembelajaran ARIAS, kemudian dilakukan pengamatan terhadap proses pembelajaran yang terjadi serta dampaknya. Tempat penelitian dilakukan di SMA Hang Tuah 1 Surabaya. Penelitian dilakukan pada tanggal 15 Januari - 31 Januari 2018. Subyek dari penelitian ini adalah 45 siswa.

Rancangan penelitian yang dilakukan dalam penelitian ini adalah one shot case study. Pengumpulan data dilakukan dengan metode:

a. Metode Tes

Tes yang diberikan berbentuk Tes Hasil Belajar. Tes ini digunakan untuk mengetahui hasil belajar dan pencapaian ketuntasan belajar oleh siswa. Tes ini diberikan setelah siswa mengikuti pembelajaran ARIAS.

b. Metode Observasi

1. Aktivitas Guru

Aktivitas guru diamati selama proses pembelajaran yang menggunakan model pembelajaran ARIAS. Lembar observasi aktivitas guru menggunakan skala Likert sesuai urutan proses pengelolaan pembelajaran.

2. Aktivitas siswa

Aktivitas siswa diamati selama proses pembelajaran sesuai tahapan ARIAS. Lembar observasi ini digunakan untuk mengetahui aktivitas dominan yang dilakukan siswa selama kegiatan pembelajaran. Nomor indikator aktivitas siswa dituliskan yang paling dominan setiap lima menit sesuai dengan indikator aktivitas siswa yang telah ditentukan, keefektifan aktifitas siswa dapat dikatakan efektif apabila aktivitas siswa yang aktif lebih besar dibandingkan dengan aktivitas siswa yang pasif.

Analisis data penelitian yang dilakukan sebagai berikut.

1. Analisis Data Ketuntasan Hasil Belajar

Data ketuntasan hasil belajar siswa dihitung berdasarkan skor tes hasil belajar yang diperoleh siswa. Siswa dikatakan tuntas belajarnya jika nilai siswa $\geq 73$ dan secara klasikal jika jumlah siswa yang tuntas mencapai $73 \%$ dari jumlah seluruh siswa. Pemberian skor tes beracuan pada pedoman penskoran yang dibuat oleh peneliti.

2. Analisis Data Aktivitas Guru

Ditetapkan skor tiap aktivitas yang dilakukan oleh guru yaitu.

$1=$ tidak baik $\quad 3=$ baik

$2=$ kurang baik $\quad 4=$ sangat baik

Kemampuan guru dalam mengelola pembelajaran dianalisis dengan mencari nilai ratarata kemampuan guru dalam mengelola pembelajaran selama dua kali pertemuan yang 
dilakukan dalam penelitian dengan katagori sangat baik. Selanjutnya nilai rata-rata tersebut dikonversikan dengan kriteria sebagai berikut:

Tabel 1. Konversi Rata-Rata Nilai Kategori Kemampuan Guru Dalam Mengelola Pembelajaran

\begin{tabular}{ll}
\hline Rata - Rata Nilai & Kriteria \\
\hline $1,00 \leq \mathrm{RNK}<1,75$ & Tidak baik \\
$1,75 \leq \mathrm{RNK}<2,50$ & Kurang baik \\
$2,50 \leq \mathrm{RNK}<3,25$ & Baik \\
$3,25 \leq \mathrm{RNK} \leq 4,00$ & Sangat baik \\
\hline
\end{tabular}

Keterangan: RNK = Rata-Rata Nilai Kemampuan Guru

3. Analisis Data Aktivitas Siswa

Data hasil pengamatan dianalisis dengan mendeskripsikan aktivitas siswa dengan langkah-langkah sebagai berikut :

- Menghitung frekuensi setiap kategori pada setiap pertemuan dari pengamatan terhadap siswa,

- Menghitung jumlah frekuensi tiap kategori pada setiap pertemuan,

- Menghitung rata-rata frekuensi setiap kategori pada setiap pertemuan,

- Mencari presentase dengan rumus: $\left(\frac{A}{B}\right) \times 100 \%$

Keterangan:

A : Rata-rata frekuensi setiap kategori

B : Jumlah frekuensi seluruh kategori

Dari pertemuan pertama sampai pertemuan terakhir, aktivitas siswa dikategorikan aktif jika jumlah rata-rata aktivitas aktif lebih besar dari jumlah rata-rata aktivitas pasif.

\section{Hasil dan Pembahasan}

Hasil penelitian menunjukkan dari analisis data Tes Hasil Belajar (THB) sebanyak 37 yang siswa tuntas dalam belajar dan 8 siswa yang tidak tuntas dalam belajar sesuai dengan kriteria KKM (Kriteria Ketuntasan Minimum) yang telah ditentukan oleh SMA Hang Tuah 1 Surabaya yaitu siswa dikatakan tuntas secara individual jika nilai yang diperoleh $\geq 73$. Hasil tersebut menunjukkan bahwa $82,22 \%$ siswa dari keseluruhan kelas.

Tabel 2. Rekapitulasi ketuntasan hasil belajar.

\begin{tabular}{clccc}
\hline No. & Nosensi & Nama Siswa & Nilai Tes & \multicolumn{2}{c}{ Keterangan } \\
${ } }$ & & $\begin{array}{c}\text { Hasil } \\
\text { Belajar }\end{array}$ & Tuntas & $\begin{array}{c}\text { Tidak } \\
\text { tuntas }\end{array}$ \\
\hline 1. & Abbie Jales Mahendra & 100 & $\sqrt{ }$ & \\
\hline 2. & Abdul Lafi Anwar & 80 & $\sqrt{ }$ & \\
\hline 3. & Achmad Farizzal Nigata & 100 & $\sqrt{ }$ \\
\hline 4. & Achamd Syaifullah Maulana & 75 & $\sqrt{ }$ \\
\hline 5. & Agus Rivanto & 85 & $\sqrt{ }$ \\
\hline 6. & Ahmad Rifa'i & 80 & $\sqrt{ }$ \\
\hline 7. & Amanda Anamita & 75 & $\sqrt{ }$ & \\
\hline 8. & Anisyah Rohimatusakdiah & 85 & $\sqrt{ }$ & \\
\hline 9. & Arief Wahyudianto & 35 & & $\sqrt{ }$ \\
\hline
\end{tabular}




\begin{tabular}{cllll}
\hline 10. & Arini Alfi Salsabila & 80 & $\sqrt{ }$ & \\
\hline 11. & Bagus Kurniawan Basuki & 75 & $\sqrt{ }$ & \\
\hline 12. & Beta Krimiasih & 80 & $\sqrt{ }$ & \\
\hline 13. & Cahyo Bimantoro & 85 & $\sqrt{ }$ & \\
\hline 14. & Dandy Jalasena & 75 & $\sqrt{ }$ & \\
\hline 15. & Deva Ramadhan Bay Haqqi & 20 & & $\sqrt{ }$ \\
\hline 16. & Devi Eniprastika & 65 & $\sqrt{ }$ & \\
\hline 17. & Evi Lusiana & 85 & $\sqrt{ }$ & \\
\hline 18. & Farid Aditya Jaya Putra & 40 & & $\sqrt{ }$ \\
\hline 19. & Febianti Nadia & 85 & $\sqrt{ }$ & \\
\hline 20. & Febrilian Bintang Satria P.P. & 40 & & $\sqrt{ }$ \\
\hline 21. & Galih Wahyu Praseya & 50 & & $\sqrt{ }$ \\
\hline 22. & Garnia Gunawang & 75 & $\sqrt{ }$ & \\
\hline
\end{tabular}

Data aktivitas guru dalam menggunakan pembelajaran ARIAS (Assurance, Relevance, Interest, Assesment, Satisfaction) pada materi statistika telah berjalan dengan baik pada pertemuan pertama dan kedua. Dari keempat aspek yang diamati pelaksanaan dan pengelolahan waktu yaitu 3,56 dan 3,5. Rata-rata dari suasana kelas yaitu 3,66. Sedangkan rata-rata yang tertinggi terdapat pada persiapan yaitu 4. Namun secara keseluruhan kemampuan guru dalam mengelola pembelajaran ARIAS (Assurance, Relevance, Interest, Assesment, Satisfaction) memperoleh rata-rata 3,68 dengan kriteria sangat baik. Jadi, guru bisa mengelola pembelajaran dengan menggunakan model pembelajaran ARIAS (Assurance, Relevance, Interest, Assesment, Satisfaction).

Tabel 3. Rekapitulasi aktivitas guru

\begin{tabular}{|c|c|c|c|c|c|}
\hline No & Aspek Yang Diamati & $\begin{array}{c}\text { RPP } \\
01\end{array}$ & $\begin{array}{c}\text { RPP } \\
02\end{array}$ & $\begin{array}{l}\text { Rata- } \\
\text { Rata }\end{array}$ & Kategori \\
\hline \multirow[t]{6}{*}{ I. } & PERSIAPAN & & & & \\
\hline & 1. Alat dan bahan & 4 & 4 & 4 & \\
\hline & Pembagian Kelompok & 4 & 4 & 4 & \\
\hline & Rencana Pelaksanaan Pembelajaran (RPP) & 4 & 4 & 4 & \\
\hline & LKS & 4 & 4 & 4 & \\
\hline & & & & 4 & Sangat Baik \\
\hline \multirow[t]{11}{*}{ II. } & PELAKSANAAN & & & & \\
\hline & A. Pendahuluan & & & & \\
\hline & $\begin{array}{l}\text { 1. } \begin{array}{l}\text { Menghubungkan materi pembelajaran hari ini dengan } \\
\text { materi yang telah dipelajari siswa } \\
\text { sebelumnya.(relevance/relevansi) }\end{array} \\
\end{array}$ & 3 & 4 & 3,5 & \\
\hline & Memotivasi siswa. (interest/minat) & 4 & 4 & 4 & \\
\hline & $\begin{array}{lll}\begin{array}{l}\text { Menyampaikan } \\
\text { (interest/minat) }\end{array} & \text { tujuan } & \text { pembelajaran } \\
\end{array}$ & 3 & 3 & 3 & \\
\hline & B. Kegiatan Inti & & & & \\
\hline & $\begin{array}{l}\text { 4. Memberikan materi secara singkat dan mengaitkan } \\
\text { contoh soal dengan kehidupan sehari-hari. }\end{array}$ & 4 & 4 & 4 & \\
\hline & Membagikan LKS. & 3 & 3 & 3 & \\
\hline & $\begin{array}{l}\text { Mengorganisasikan siswa } \\
\text { belajar. }\end{array}$ & 3 & 4 & 3,5 & \\
\hline & $\begin{array}{l}\text { Meminta siswa untuk mengerjakan LKS secara } \\
\text { individu. (assesment/penilaian) }\end{array}$ & 3 & 3 & 3 & \\
\hline & $\begin{array}{l}\text { Meminta siswa untuk mendiskusikan LKS dengan } \\
\text { kelompoknya. }\end{array}$ & 3 & 3 & 3 & \\
\hline
\end{tabular}




\begin{tabular}{|c|c|c|c|c|c|c|}
\hline & 9. & $\begin{array}{l}\text { Berkeliling ke bangku-bangku siswa untuk } \\
\text { memberikan bantuan jika diperlukan dan untuk } \\
\text { mengontrol siswa selama bekerja dalam kelompok. }\end{array}$ & 4 & 4 & 4 & \\
\hline & 10. & $\begin{array}{llr}\text { Meminta perwakilan } & \text { kelompok untuk } \\
\text { mempresentasikan } & \text { hasil } & \text { diskusinya. } \\
\text { (Assurance/percaya diri) } & & \\
\end{array}$ & 4 & 4 & 4 & \\
\hline & 11. & Membimbing presentasi kelompok & 3 & 4 & 3,5 & \\
\hline & 12. & $\begin{array}{l}\text { Memberi umpan balik terhadap presentasi yang telah } \\
\text { dilakukan. }\end{array}$ & 4 & 4 & 4 & \\
\hline & 13. & $\begin{array}{l}\text { Memberikan penghargaan berdasarkan kinerja siswa } \\
\text { selama pembelajaran. (satisfaction/penguatan) }\end{array}$ & 3 & 4 & 3.5 & \\
\hline \multicolumn{7}{|c|}{ C. Penutup } \\
\hline & 14. & Membimbing siswa membuat rangkuman. & 3 & 4 & 3,5 & \\
\hline & 15. & Memberikan PR & 3 & 3 & 4 & \\
\hline & 16. & $\begin{array}{l}\text { Meminta siswa untuk mempelajari materi selanjutnya } \\
\text { dirumah. }\end{array}$ & 3 & 4 & 3,5 & \\
\hline & & & & & 3,56 & Sangat baik \\
\hline III & \multicolumn{2}{|c|}{ PENGELOLAAN WAKTU } & 3 & 4 & 3,5 & Sangat baik \\
\hline
\end{tabular}

\begin{tabular}{clrrrr}
\hline IV & SUASANA KELAS & & & & \\
\hline 1. & Berpusat pada siswa & 4 & 4 & 4 & \\
\hline 2. & Siswa antusias selama pembelajaran & 4 & 3 & 3,5 & \\
\hline 3. & Guru antusias & 3 & 4 & 3,5 & \\
\hline & & & & $\mathbf{3 , 6 6}$ & Sangat baik \\
\hline & Rata-rata seluruh aspek & & $\mathbf{3 , 6 8}$ & Sangat baik \\
\hline
\end{tabular}

Analisis data aktivitas siswa tentang 10 kategori yang diobservasi, ternyata aktivitas yang paling dominan adalah mengerjakan LKS dengan kelompok sebesar 16,4\%. Hal ini dikarenakan dalam pembelajaran ARIAS lebih ditekankan pada diskusi kelompok dalam mengerjakan LKS pada setiap pembelajaran. Aktivitas siswa yang paling rendah adalah perilaku yang tidak relevan dengan presentase sebesar $1,56 \%$. Selain itu aktivitas untuk berdiskusi atau bertanya dengan teman dan guru dengan presentase masing-masing sebesar $12,5 \%$ dan $14,48 \%$. Aktivitas siswa yang pasif yaitu $21,47 \%$ sedangkan aktivitas siswa yang aktif yaitu 78,49\%. Ini berarti jumlah rata-rata aktivitas siswa yang aktif lebih besar dibandingkan dengan jumlah rata-rata aktivitas siswa yang pasif.

Tabel 4. Rekapitulasi Aktivitas Siswa

\begin{tabular}{|c|c|c|c|c|c|c|c|c|c|c|c|c|}
\hline \multirow[t]{2}{*}{ No. } & \multirow[t]{2}{*}{ Pertemuan } & \multicolumn{10}{|c|}{ Aktivitas Siswa } & \multirow{2}{*}{$\begin{array}{c}\text { Frekue } \\
\text { nsi }\end{array}$} \\
\hline & & 1 & 2 & 3 & 4 & 5 & 6 & 7 & 8 & 9 & 10 & \\
\hline 1. & Pertama & 11 & 15 & 8 & 16 & 21 & 20 & 8 & 17 & 10 & 2 & 128 \\
\hline 2. & Kedua & 11 & 14 & 12 & 16 & 21 & 18 & 8 & 14 & 12 & 2 & 128 \\
\hline \multicolumn{2}{|c|}{ Frekuensi } & 22 & 29 & 20 & 32 & 42 & 38 & 16 & 31 & 22 & 4 & 256 \\
\hline \multicolumn{2}{|r|}{$\%$} & 8,59 & 11,32 & 7,81 & 12,5 & 16,4 & 14,84 & 6,25 & 12,1 & 8,59 & 1,56 & \\
\hline
\end{tabular}

Dari hasil analisis hasil belajar siswa tentang siswa yang tuntas lebih banyak daripada siswa yang tidak tuntas menunjukkan bahwa pembelajaran ARIAS (Assurance, Relevance, Interest, Assesment, Satisfaction) yang dikembangkan dikatakan efektif sebagai model pembelajaran matematika. Sedangkan hasil analisis aktivitas guru pada materi statistika telah berjalan dengan baik pada pertemuan pertama dan kedua. Rata-rata keseluruhan adalah 3,68 dengan kriteria sangat baik. Hal ini menunjukan bahwa peran guru yang sangat baik merupakan salah satu komponen penting dalam suatu pembelajaran. Menurut Woodruff seperti dikutip oleh Trianto (2009:23) bahwa sesungguhnya belajar tidak terjadi tanpa minat/perhatian. Dengan 
demikian, betapa pentingnya bagi guru untuk menanamkan sikap percaya diri ini pada siswa guna mendorong dan memotivasi diri mereka untuk berhasil dan berprestasi secara optimal sehingga mampu bersaing dengan teman-temannya dalam pembelajaran.

Hasil analisis aktivitas siswa lebih dominan mengerjakan LKS dengan kelompok. Hal ini dikarenakan dalam pembelajaran ARIAS lebih ditekankan pada diskusi kelompok dalam mengerjakan LKS pada setiap pembelajaran. Dalam pembelajaran ini peran guru berubah, dimana guru sebagai fasilitator, moderator, organisator dan mediator belajar terlihat jelas. Sehingga peran dan fungsi siswa terlihat, keaktifan semua siswa akan dapat memberikan suasana aktif, terkesan demokratis dan masing-masing siswa punya peran penting serta akan memberikan pengalaman belajarnya kepada siswa lain.

\section{Simpulan dan Saran}

Dari hasil penelitian dapat disimpulkan bahwa pembelajaran statistika dengan model pembelajaran ARIAS dapat diterapkan dengan baik berdasarkan ketuntasan hasil belajar melebihi nilai KKM yaitu $\geq 73$, dan aktivitas guru dalam mengelola kelas dapat dikategorikan sangat baik, aktivitas siswa yang aktif lebih besar daripada aktivitas siswa yang pasif.

Saran yang disampaikan untuk penelitian selanjutnya adalah siswa harus selalu percaya diri dalam mengungkapkan pendapat, guru harus selalu memotivasi siswa untuk berani mengungkapkan pendapat, sehingga pembelajaran tidak terpusat pada guru, tetapi siswa pun ikut andil dalam merumuskan masalah, serta model pembelajaran ARIAS (Assurance, Relevance, Interest, Assesment, Satisfaction) hendaknya digunakan sebagai salah satu alternatif pembelajaran dalam penyampaian materi pelajaran matematika.

\section{Referensi}

Ahmadi, Iif, K \& Amri, S. 2014. Pengembangan Dan Model Pembelajaran Tematik Integratif. Jakarta: PT Prestasi Pustakarya.

Arikunto, S. 2006. Prosedur Penelitian Suatu Pendekatan Praktik. Jakarta: Rineka Cipta.

Chatib, Munif. 2012. Gurunya Manusia: Menjadikan Semua Anak Istimewah dan Semua Anak Juara. Bandung: Kaifa.

Heruman. 2007. Model Pembelajaran Matematika. Bandung: PT Remaja Rosdakarya.

https://www.kajianpendidikan.com/2014/02/pengertian-pembelajaran-matematika.html.

https://www.psychologymania.com/2012/12/karakteristik-pembelajaran-matematika.html.

https://www.researchgate.net/publication/321835753_Efektivitas_Model_Pembelajaran_ARIA S_Assurance_Relevance_Interest_Assessment_Satisfaction_dalam_Meningkatkan_Has il_Belajar_Matematika_Siswa_SMP_Muhammadiyah_58_Medan

Peraturan Menteri Pendidikan Nasional Nomor 22 Tahun 2006 tanggal 23 Mei 2006 tentang Standar Isi diakses 10 Oktober 2013.

Rahman, M. \& Amri, S. 2014. Model Pembelajaran ARIAS Integratif. Jakarta: PT Prestasi Pustakarya.

Slameto. 2010. Belajar dan Faktor-Faktor yang Mempengaruhi Belajar. Jakarta: Rinerka Cipta. 
Slavin, Robert. E. 1997. Educational Psycology America: Alyn \& Bacon.

Suherman, E. dkk. 2003. Strategi Pembelajaran Matematika Kontemporer. Bandung: UPI.

Soyomukti, N. 2008. Pendidikan Berspektif Globalisasi. Jogjakarta. AR-Ruzz Media.

Suwitaningrum, T. 2012. Skripsi Meningkatkan Keaktifan Belajar Matematika Siswa Kelas VII-

B MTs Darut Tauhid Pada Pokok Bahasan Segi Empat Melalui Penerapan Model Pembelajaran Kooperatif Tipe ARIAS. Surabaya: Universitas Muhammadiyah Surabaya.

Tilawa, Ikhtiar Sari. 2013. Skripsi Penerapan Strategi Belajar Assurance, Relevance, Interest, Assesment Dan Satisfaction (Arias) Terhadap Hasil Belajar Dan Motivasi Berprestasi Siswa Pada Standart Kompetensi Membuat Rekaman Audio Di Studio di SMK Negeri 3 Surabaya. Surabaya: Universitas Negeri Surabaya. 